The Classical Quarterly

http://journals.cambridge.org/CAQ

Additional services for The Classical Quarterly:

Email alerts: $\underline{\text { Click here }}$

Subscriptions: $\underline{\text { Click here }}$

Commercial reprints: Click here

Terms of use : $\underline{\text { Click here }}$

\title{
The wolf and the dog (Horace, Sermones 2.2.64)
}

L. B. T. Houghton

The Classical Quarterly / Volume 54 / Issue 01 / May 2004, pp 300 - 304

DOI: 10.1093/cq/54.1.300, Published online: 07 April 2006

Link to this article: http://journals.cambridge.org/abstract_S0009838804000308

How to cite this article:

L. B. T. Houghton (2004). The wolf and the dog (Horace, Sermones 2.2.64). The Classical Quarterly, 54, pp 300-304 doi:10.1093/cq/54.1.300

Request Permissions : $\underline{\text { Click here }}$ 
THE WOLF AND THE DOG (HORACE, SERMONES 2.2.64)*

At Sat. 2.2.63-4 Horace's reader is faced with a dilemma: should he or she follow the example of Avidienus, the squalor of whose hospitality repels those unwary enough to accept his invitation, or that of hosts who serve up peacocks and mullets on the strength of their size and appearance rather than their taste? The choice offered by Ofellus, who serves as the mouthpiece for Horace's moralizing in this satire, is between the contrasting poles of meanness and extravagance, and the difficulty of determining which option constitutes the lesser evil is expressed in terms of a traditional proverb: ${ }^{1}$ hac urget lupus, hac canis, aiunt $(2.2 .64$, 'on this side presses the wolf, on this the dog, as they say'). The use of this image to denote a choice between two equally disagreeable alternatives dates back at least as far as Plautus (Casina 970-2 - and even in this passage it is described as an old saying, verbum vetus), and its incarnation here in Horace could be taken to imply nothing more than that avarice and needless luxury are opposites, to be avoided in both cases. Indeed, the proverb is particularly suited to the context of its application at line 64, since the traditional polarity of dogs and wolves here reflects a choice between characteristics or lifestyles of which the dog and the wolf respectively were commonly taken as illustrations, namely squalid degradation and wilful rapacity. ${ }^{2}$ The point is not lost on the ancient scholia, which gloss lupus as prodigus luxuria and canis as perditus avaritia (ps.-Acro ad loc.). ${ }^{3}$

It is clear, then, that Horace has introduced the proverbial opposition of dog and

* I am very grateful to Professor M. D. Reeve and Dr N. J. Richardson for discussion of issues relating to the content of this note.

1 The proverbial nature of the phrase is signalled by the generalizing aiunt ('as they say'): see commentators (Muecke, Palmer, Kiessling-Heinze) ad loc. For the proverb, see A. Otto, Die Sprichwörter und sprichwörtlichen Redensarten der Römer (Leipzig, 1890; repr. Hildesheim, 1962), s.v. lupus 8, citing T. Bergk, Philologus 32 (1873), 566.

2 Cf. e.g. Hor. Epist. 1.2.26 (canis immundus), Epod. 16.20 (rapacibus lupis), Carm. 4.4.50 (luporum praeda rapacium); Verg. Aen. 2.355-6 (lupi ceu / raptores); Otto, Sprichwörter, s.v. lupus 1.

${ }^{3}$ See also Porphyrio ad loc.: per lupum et canem significat ex una parte luxuriam ex alia avaritiam imminere ('by means of the wolf and the dog he signals that from one direction luxury threatens, from another avarice'). 
wolf with an eye to its peculiarly apposite relevance in this setting; his use of the expression is bound even more closely to what precedes it when we recall that the embodiment of avarice whose sordid existence Ofellus has just described, Avidienus, is himself known by the nickname 'dog' (2.2.55-6, Avidienus, / cui Canis ex vero ductum cognomen adhaeret). The significance of this representative of immunditia actually being called 'dog' in the light of the proverb which follows has not escaped the notice of commentators ancient or modern, who observe that the canis of line 64 can scarcely fail to call to mind the human Canis of lines $55 \mathrm{ff}^{4}{ }^{4}$ If we accept this connection - and it is by no means an unnatural one to make - a further question immediately presents itself: if Avidienus, nicknamed 'the dog', is figured in the proverb as the importunate dog, then to whom does his proverbial counterpart the wolf refer? ${ }^{5}$ The contrast between dog and wolf evidently represents an antithesis of Avidienus and a partisan of the lifestyle at the other end of the spectrum to that which he adopts, so that we are obliged to look in the section on extravagant tastes that comes before the lines dealing with Avidienus if we are to identify the human 'wolf' implied by the association of canis with Canis later in the poem.

In this passage we meet two individuals, the praeco Gallonius at lines $46-8$ and an unnamed praetor who is reported in lines $49-50$ to have introduced the custom of dining on storks and sturgeon. This praetorius auctor is identified by Porphyrio as Rufus, an unsuccessful candidate for the praetorship, responsible for bringing storks into culinary fashion (Porph. ad 2.2.50). Gallonius the auctioneer appears in a number of fragments of the early Roman satirist Lucilius, where he is condemned for gluttony and for his penchant for outsize seafood. The following extract from Cicero's De finibus preserves verses which seem to have been put by Lucilius into the mouth of C. Laelius, the friend and confidant of Lucilius' patron Scipio Africanus: ${ }^{6}$

$$
\text { illudque vere: }
$$

'o Publi, o gurges, Galloni, es homo miser,' inquit. 'cenasti in vita numquam bene, cum omnia in ista consumis squilla atque acipensere cum decimano'

is haec loquitur qui in voluptate nihil ponens negat eum bene cenare qui omnia ponat in voluptate; et tamen non negat libenter umquam cenasse Gallonium (mentiretur enim), sed bene. ita graviter et severe voluptatem secernit a bono. ex quo illud efficitur, qui bene cenent omnes libenter cenare, qui libenter, non continuo bene. semper Laelius bene. quid bene? dicet Lucilius:

condito,

cocto,

sed cedo caput cenae:

quid ex eo? sermone bono,

si quaeris, libenter.

${ }^{4}$ N. Rudd, The Satires of Horace (Cambridge, 1966), 143; cf. ps.-Acro ad loc.

${ }^{5}$ Horace's use of canis elsewhere, combined with the squalid habits displayed by Avidienus, may suggest a philosophical allegiance to Cynicism (cf. J. S. C. Eidinow, CQ 40 [1990], 566-8 on canis at Hor. Epist. 1.2.26 and 2.2.75), but there is no clear counterpart in terms of an adherent of a school of philosophy being characterized as a 'wolf' (contrast the use of 'pig' for Epicureans in the passages cited) - unless perhaps we recall the etymology of Aristotle's Lyceum.

${ }^{6}$ Cic. Fin. 2.8.24-5; cf. Lucil. fr. 1238-40 Marx (fr. 1133-5 Krenkel). On this passage and its relation to Gallonius in Sat. 2.2, see G. C. Fiske, Lucilius and Horace. A Study in the Classical Theory of Imitation (Madison, 1920), 384; Muecke ad Sat. 2.2.23-52, 47. For other possible echoes of Lucilius in this poem, see Fiske 381-7. 
This too is true: 'O Publius Gallonius, you voracious whirlpool, you're a wretched man,' says he. 'You've never dined well in your life, when you're wasting everything on that squill, and on that enormous sturgeon.' The man who speaks this is one who, setting pleasure at naught, denies that the man who sets pleasure at everything can dine well; and yet he does not deny that Gallonius ever dined with enjoyment (for he'd be lying if he did), but that he ever dined well. In this way he solemnly and strictly sets pleasure apart from what is good. From this it results that all those who dine well dine with enjoyment, but those who dine with enjoyment don't therefore dine well. Laelius always dined well. What is 'well', then? Lucilius will tell us: 'with food well cooked and seasoned'-but here's the principal ingredient of the dinner-'with good conversation' - and what does that work out as? - 'dining with enjoyment, if that's what you're asking.'

Gallonius praeco thus appears in Horace's satiric model Lucilius, and his name is raised as a candidate for the role of lupus by the scholiast pseudo-Acro. ${ }^{7}$ If one of the fish favoured by Gallonius was the pike (lupus), then the references to lupus... Tiberinus at line 31 and to proceri ... lupi at line 36 of this satire might lend some relevance to his being the lupus of the proverb; but the passage of Lucilius mentions squilla and acipenser as Gallonius' preferred monstrosities, not lupus, and in any case lupi are introduced in 2.2.36 as an alternative to mullet, and therefore despised by the extravagant. In fact, neither of these suggestions provides us with an acceptable counterpart to Avidienus, since neither makes any specific connection between Gallonius or Rufus and wolves, and whereas Avidienus the dog is the only example of stinginess cited, if we have to choose one of the practitioners of gluttony it is difficult to know which is its more natural representative, and hence the obvious choice for Avidienus' opposite. It seems we shall have to look elsewhere.

Within the generic context of Roman satire as a whole, and in particular in this passage suffused with Lucilian echoes, one name does suggest itself - and that name is, indeed, Lupus. We know from Horace himself and from elsewhere that Lucilius, whom Horace claims to follow (sequor hunc, Sat. 2.1.34), had satirized one L. Cornelius Lentulus Lupus, consul in 156 B.C., ${ }^{8}$ and a comment of Servius asserts that Lucilius' first book of satires had as its subject a council of the gods held to discuss the death of 'a certain Lupus, a leader in the state'. ' That Lucilius' Lupus would have occurred to Horace's readers at this point in the Sermones can be argued not only from the status of Lucilius as 'modello-codice' for Roman satirical writing, to employ Conte's terminology, ${ }^{10}$ but also from the fact that Lupus has been named as one of Lucilius' victims in the preceding satire: aut laeso doluere Metello / famosisque Lupo cooperto versibus? (Sat. 2.1.67-8, 'Were they [Lucilius' patrons Laelius and Scipio] aggrieved at the slight to Metellus, or at Lupus' being smothered by scurrilous verses?'). Lucilius' attack on Lupus would thus be fresh in the mind of anyone who had come to this poem after

${ }^{7}$ Ps.-Acro ad loc., followed among modern commentators by Palmer (ad 2.2.64) and by Rudd in the notes to his translation of the Satires (revised edn, Harmondsworth, 1987), 251.

${ }^{8}$ T. R. S. Broughton, The Magistrates of the Roman Republic (New York, 1951), 1.447. In addition to the fragments of Lucilius that follow, cf. Persius 1.114-5: . . secuit Lucilius urbem, / te Lupe, te Muci, et genuinum fregit in illis ('Lucilius lashed the city-you, Lupus, you, Mucius - and broke his jaw on them').

9 Serv. ad Aen. 10.104: totus hic locus de primo Lucili translatus est libro, ubi inducuntur di habere concilium et agere primo de interitu Lupi cuiusdam ducis in re publica, postea sententias dicere ('this whole passage is taken from the first book of Lucilius, where the gods are brought in holding a council, treating first of all of the death of one Lupus, a leading statesman, and afterwards giving their judgements').

${ }^{10}$ G. B. Conte, The Rhetoric of Imitation: Genre and Poetic Memory in Virgil and Other Latin Poets, trans. and ed. C. P. Segal (Ithaca and London, 1986), 31; see also S. E. Hinds, Allusion and Intertext: Dynamics of Appropriation in Roman Poetry (Cambridge, 1998), 41 with n.46. 
reading the end of the programmatic introduction to the second book. Whether Lupus could naturally be read into the proverbial lupus of 2.2.64 must, of course, depend in part on what vices were attributed to him by Lucilius, and whether these can be viewed as corresponding, in the opposite sphere of conduct, to the extremes imputed by Horace and Ofellus to the canis Avidienus.

At Cicero, De Natura Deorum 1.23.63 (=Lucil. fr. 1312-13 Marx, fr. 1328-30 Krenkel) the poet appears to be incorporating Lupus' name in the list of those whom he is castigating for their perjury:

quid de sacrilegis, quid de impiis periurisque dicemus?

Turbulus si Lucius umquam,

si Lupus aut Carbo aut Neptuni filius,

ut ait Lucilius, putasset esse deos, tam periurus aut tam impurus fuisset?

What shall we say of the sacrilegious, what of the impious and the perjured? 'If ever Lucius Turbulus, if Lupus or Carbo or a son of Neptune', as Lucilius says, had thought that the gods exist, would he have been so perjured or so corrupt?

Clearly we cannot set this against the shortcomings of Avidienus, since the two failings are not comparable, and do not form two extremes of the same spectrum: with some effort, no doubt, it is quite possible to be both sordid and perjured - even simultaneously. ${ }^{11}$ In a fragment attributed to Lucilius' first book, however, we find a prediction as to the manner of Lupus' imminent demise, which assigns responsibility for his death to two varieties of exotic seafood: ${ }^{12}$ occidunt, Lupe, saperdae te et iura siluri! ('they're destroying you, Lupus - sardines and perch-sauces!'). As Varro explains, piscium nomina sunt eorumque in Graecia origo (Ling. 7.47, 'these are names of fish and their origin is in Greece'): although the grammarian Festus (De Verb. Sign. 324-5 Müller) calls the saperda 'genus pessimi piscis', a species of quite dreadful fish, suggesting that it was far from fêted for its culinary qualities, ${ }^{13}$ the fact that it had to be imported from Greece (or even from Egypt) might be taken to support its status as a recherché commodity, difficult to obtain and costly to transport despite the poor return it offered when finally served up in Rome. To judge from this Lucilian fragment, then, Lupus could well have appeared in the earlier satirist as a perpetrator of the kind of ludicrous innovations in contemporary cuisine attacked by Horace in Sat. 2.2-innovations which, in this case, not only demonstrate useless pretension on the part of their sponsor, but are actually contributing to his downfall.

A further couplet from Lucilius' opening book of satires, preserved by Nonius, records what seems to be either a threat or a promise to issue an invitation to dinner; given the subject of this first book, it is not too great a leap to suppose that the speaker of these lines may have been Lupus, the principal target of Lucilius' pen at this point in the Satires. The dinner in question is once again to involve fish, the particular delicacies to be served being enumerated in gleeful anatomical detail: ${ }^{14}$

${ }^{11}$ In Lucil. fr. 784-90 Marx (= fr. 789-95 Krenkel) Lupus' excesses in relation to the law are again satirized, the target here being his voracity - not, however, of a gastronomic variety.

${ }^{12}$ Varro, Ling. 7.47 (= Lucil. fr. 54 Marx, fr. 55 Krenkel). For possible puns on both lupus and iura here, see E. H. Warmington, Remains of Old Latin III, Loeb Classical Library 329 (Cambridge, MA and London, 1967), 16-17.

13 'A fish of small account': D'Arcy W. Thompson, A Glossary of Greek Fishes (London, 1947), 226 s.v. $\sigma \alpha \pi \epsilon ́ \rho \delta \eta s$, with refs.

${ }^{14}$ Nonius 159.29 (= Lucil. fr. 49-50 Marx, fr. 53-4 Krenkel). The tunnus and acarne mentioned 
ad cenam adducam, et primum hisce abdomina tunni advenientibus priva dabo cephalaeaque acarnae.

I'll invite them to dinner, and when they first turn up I'll give them each tuna bellies and sea-perch head-pieces.

Puelma Piwonka sees in these lines evidence for Lupus' character as 'Gräkomane', the affectation of his speech expressive of 'das sinn- und maßlose Raffinement der Speisen und Getränke'. ${ }^{15}$ The epicure's absurd relish in naming the specific body-parts that will form his menu is surely comparable to the foible satirized by Horace not only in Catius' exposition of his unnamed master's ars vivendi in Sat. 2.4, but also in the lines on the provenance and weight of the glutton's favoured fish (2.2.31-8) which precede the discussion of Gallonius, the 'praetor' and Avidienus in Sat. 2.2.

In conclusion, if it is reasonable to surmise that Lupus was lampooned by Lucilius for (among other vices) an unusually recherché taste in affairs of the kitchen, the connection between the Lupus of earlier Roman satire and the lupus of Horace's proverb becomes a natural association to make. It provides an exact parallel to the relationship between Avidienus, nicknamed Canis, and the canis with whom he is identified at Sat. 2.2.64 and the precision of the parallel, far from detracting from the humour in Horace's punning use of the verbum vetus, adds yet another element to the cleverness of the poet's insertion of this proverb at this particular point in the poem (and the collection). It is only by avoiding the excesses of both the miserly Avidienus and Lucilius' extravagant villain that the reader of the Satires will be able to keep the wolf — and indeed the dog — from the door.

\author{
Trinity College, Cambridge \\ L. B. T. HOUGHTON \\ lbth2@cam.ac.uk
}

in this fragment appear in the elder Pliny's catalogue of fish peculiares ... maris (Plin. NH 32.145-52 - but note thynni also in ibid. 145, amni . . ac mari) alongside the squilla and acipenser of the lines on Gallonius quoted above.

${ }^{15}$ M. Puelma Piwonka, Lucilius und Kallimachos. Zur Geschichte einer Gattung der hellenistisch-römischen Poesie (Frankfurt am Main, 1949), 29. 